PROFESI (Profesional Islam)

Media Publikasi Penelitian; 2017; Volume 15; No 1.

Website: ejournal.stikespku.ac.id

\title{
Faktor-Faktor Yang Berhubungan Dengan Status Gizi Balita Yang Mengikuti Tfe di Kabupaten Sukoharjo
}

\author{
Wynsdy Fajar Apriliana ${ }^{1^{*}}$, Luluk Ria Rakhma ${ }^{2}$ \\ ${ }^{1}$ Prodi Ilmu Gizi/Fakultas Ilmu Kesehatan, Universitas Muhammadiyah Surakarta \\ ${ }^{2}$ Prodi Ilmu Gizi/Fakultas Ilmu Kesehatan, Universitas Muhammadiyah Surakarta \\ *Email: windyfajar@gmail.com
}

\begin{abstract}
Kata Kunci
Faktor tidak langsung, TFC,

Status gizi, Balita
\end{abstract}

\begin{abstract}
Abstrak
Beberapa faktor tidak langsung yang mempengaruhi status gizi balita yaitu pendapatan keluarga, pendidikan ibu, pengetahuan ibu, dan besar keluarga. TFC merupakan program pemerintah yang diselenggarakan dengan tujuan untuk mengurangi angka gizi buruk dan kurang pada balita. Jenis penelitian ini menggunakan pendekatan cross sectional terdapat 30 responden diperoleh dengan teknik simple random sampling dengan uji statistik Rank Spearman. Responden dengan pendapatan perkapita kurang (60\%) dan pendapatan perkapita cukup (40\%), pendidikan ibu $<9$ tahun (50\%) dan pendidikan ibu $>9$ tahun (50\%), pengetahuan ibu kurang (50\%) dan pengetahuan ibu cukup (50\%), besar keluarga kategori kecil (80\%) dan besar keluarga kategori besar (20\%). Responden balita dengan status gizi kurang (60\%) dan status gizi buruk (40\%). Nilai p value dari analisis hubungan antara status gizi terhadap pendapatan perkapita, pendidikan ibu, pengetahuan ibu, dan besar keluarga masing-masing adalah 0.634, 0.522, 0.348, dan 0.738. Tidak terdapat hubungan yang signifikan antara pendapatan perkapita, pendidikan ibu, pengetahuan ibu, dan besar keluarga dengan status gizi balita yang mengikuti TFC.
\end{abstract}

\section{The Factors That Are Correlated With Nutritional Status Of Toddlers Who Joined Tfe In, Sukoharjo}

Keywords

Indirect factors, TFC,

Nutritional status, Toddlers

\begin{abstract}
As for several indirect factors which affect nutritional status of toddlers are family income, mother's education, mother's knowledge, and size of family. TFC is a government program which is held with the aim to reduce the rate of malnutrition in toddlers. The research used cross sectional design. Thirty respondents were obtained by simple random sampling technique with statistical tests of Rank Spearman. Number of respondents with low per capita income was $60 \%$ while those who had sufficient per capita income was $40 \%$, mother's with basic education was 50\% and mother's with advanced education was 50\%, mother's who had low knowledge was 50\% and mother's knowledge moderate was $50 \%$, family size at small category was $80 \%$ and big family was $20 \%$. Respondents with malnutrition was $60 \%$ and severe malnutrition status was $40 \%$. P values of relationship analyze between nutritional status towards per capita income, mother's education, mothers's knowledge, and size of family were $0.634,0.522,0.348$, and 0.738 respectively. There was no significant relationship between per capita income, mother's education, mother's knowledge, and size of family with nutritional status of toddlers who joined TFC (Therapeutic Feeding Center).
\end{abstract}


PROFESI (Profesional Islam) Media Publikasi Penelitian; 2017; Volume 15; No 1.

Website: ejournal.stikespku.ac.id

\section{PENDAhuluan}

Gizi merupakan salah satu penentu kualitas sumber daya manusia. Kondisi gizi baik dapat dicapai bila tubuh memperoleh cukup zat gizi yang dikonsumsi sehingga memungkinkan terjadinya pertumbuhan fisik, perkembangan otak, dan kemampuan untuk mencapai tingkat kesehatan optimal (Depkes RI, 2003).

Menurut Olaf dan Michael (2005), masalah gizi kurang banyak terjadi di negara-negara berkembang seperti di Asia salah satunya Indonesia (Bunga dkk, 2015). Menurut data Riskesdas 2013, prevalensi balita gizi buruk dan kurang di Indonesia menurut BB/U mencapai $19,6 \%$, terdiri dari 5,7 persen gizi buruk dan 13,9 persen gizi kurang. Angka tersebut meningkat dibandingkan data Riskesdas 2010 sebesar 17,9\% dan Riskesdas 2007 sebesar $18,4 \%$.

Gizi kurang merupakan salah satu faktor penyumbang tingginya angka kesakitan dan kematian yang terjadi pada balita (Hickson, 2006). Menurut Kemenkes RI (2007), bila seseorang tidak mendapatkan asupan gizi yang cukup akan mudah sakit dan mudah terkena penyakit, sehingga menyebabkan gangguan nafsu makan, mengakibatkan asupan gizi menjadi berkurang dan menyebabkan gizi kurang. Hal ini disebabkan karena, kebutuhan nutrisi untuk balita tinggi digunakan untuk pertumbuhan dan pengembangan balita (WHO, 2005).

Masalah gizi kurang umumnya disebabkan oleh beberapa faktor. Faktor-faktor tersebut terbagi menjadi dua yaitu faktor langsung dan tidak langsung. Faktor langsung status gizi yaitu asupan makanan dan penyakit infeksi (WHO, 2007). Adapun faktor tidak langsung status gizi yaitu ketahanan pangan di dalam keluarga, pola asuh, sanitasi lingkungan, akses terhadap pelayanan kesehatan, umur anak, jenis kelamin anak, tempat tinggal, pendidikan, pengetahuan, besar keluarga, pendapatan dan pekerjaan orang tua (Vitolo, 2008).

Besar keluarga mempengaruhi status gizi karena semakin banyak anggota keluarga maka pembagian pangan untuk setiap anak akan berkurang. Jumlah anak yang banyak diikuti dengan distribusi makanan yang tidak merata akan menyebabkan anak balita dalam keluarga tersebut menderita kurang gizi (Ihsan, 2012). Hal ini dapat berakibat turunnya nafsu makan anak sehingga pemenuhan kebutuhan primer anak seperti konsumsi makanannya akan terganggu dan hal tersebut akan berdampak terhadap status gizi anaknya (Panambunan dan Sjane, 2006).

Penelitian Zulfita (2013) menyebutkan bahwa, pola asuh ibu, status ekonomi, fasilitas kesehatan serta penyakit infeksi ada hubungannya dengan status gizi pada balita. Penelitian Baiq (2015), menyebutkan faktor-faktor status gizi pada balita adalah pengetahuan gizi, pekerjaan ibu, dan pendapatan keluarga. Faktorfaktor tersebut dapat menyebabkan gizi kurang pada balita.

Menurut Notoatmodjo (2007) Pengetahuan dapat berhubungan dengan status gizi balita, karena pengetahuan kurang atau baik akan sangat berpengaruh pada perilaku ibu dalam memper-hatikan asupan makanan bergizi bagi balita. Hal tersebut sesuai dengan penelitian Ismi (2014) bahwa terdapat hubungan antara pengetahuan ibu dengan status gizi balita mengenai pemahaman pemberian makanan serta penerapan pengetahuan yang diperoleh dalam kehidupan sehari-hari.

Menurut Ermaningsih (2007) bahwa faktor yang dapat mempengaruhi status gizi balita adalah tingkat pendidikan formal orang tua terutama tingkat pendidikan formal ibu, karena tingkat pendidikan ibu sangat penting dalam memenuhi kebutuhan gizi balitanya. Semakin tinggi tingkat pendidikan seseorang maka semakin mudah diberikan pengertian mengenai suatu informasi dan semakin mudah untuk mengimplementasikan pengetahuannya dalam perilaku khususnya dalam hal kesehatan dan gizi. Pendidikan ibu yang relatif rendah juga akan berkaitan dengan sikap dan tindakan ibu dalam menangani masalah kurang gizi pada anak balitanya (Atmarita, 2004).

Menurut Syafiq (2007) salah satu faktor yang berhubungan dengan status gizi seseorang 
PROFESI (Profesional Islam) Media Publikasi Penelitian; 2017; Volume 15; No 1.

Website: ejournal.stikespku.ac.id

adalah tingkat pendapatan keluarga. Karena keluarga dengan pendapatan terbatas kemungkinan besar akan kurang dapat memenuhi kebutuhan makanannya terutama untuk memenuhi kebutuhan zat gizi dalam tubuhnya.

Komitmen Kementerian Kesehatan untuk memulihkan keadaan gizi kurang dan gizi buruk di masyarakat ditunjukkan dengan penyediaan Pusat Pemulihan Gizi (PPG) atau Therapeutic Feeding Center (TFC) di Puskesmas. Pusat Pemulihan Gizi (PPG) berfungsi sebagai tempat perawatan dan pengobatan anak gizi buruk dan gizi kurang secara intensif di suatu ruangan khusus. Di ruangan khusus ibu atau keluarga terlibat dalam perawatan anak tersebut. Tahun 2010 terdapat 95 PPG (Kemenkes RI, 2011). Program TFC meliputi pemberian pendidikan atau edukasi pada ibu balita yaitu memberi edukasi mengenai cara merawat anak yang baik serta cara pemberian makanan tinggi kalori dan protein dengan menggunakan aneka bahan makanan setempat (Dirjen Kesmas RI, 2011). Selain itu, Pemberian Makanan Tambahan (PMT) juga merupakan program TFC yang bertujuan untuk menambah berat badan pada balita gizi kurang (Kemenkes RI, 2011).

Berdasarkan data yang diperoleh dari survei pendahuluan yang peniliti lakukan prevalensi gizi kurang di Kabupaten Sukoharjo bulan 2016 sebesar 4,98\% (2476 balita) sedangkan prevalensi gizi buruk sebesar 0,58\% (286 balita). Prevalensi gizi kurang paling tinggi berada di Kecamatan Grogol sebesar 4,62\% (227 balita), sedangkan prevalensi gizi kurang paling rendah berada di Kecamatan Bulu sebesar 3,55\% (63 balita). Prevalensi gizi buruk tertinggi berada di Kecamatan Grogol sebesar 0,74\% (51 balita), sedangkan prevalensi gizi buruk paling rendah berada di Kecamatan Nguter sebesar 0,37\% (10 balita).

Program TFC dilaksanakan setiap tahun secara bergilir, dalam satu tahun ada tiga kecamatan yang mendapatkan TFC. Kegiatan dalam program TFC meliputi Pemberian Makanan Tambahan (PMT), penimbangan antropometri, pemberian paket modisco, pemeriksaan kesehatan, edukasi gizi, dan evaluasi penimbangan antropometri yang dilakukan satu minggu sekali. TFC tahun 2016 berada di Kecamatan Gatak, Kecamatan Weru, dan Kecamatan Sukoharjo dengan total populasi 50 balita. Selain itu, alasan lain pengambilan sampel penelitian di Kabupaten Sukoharjo karena sudah menerapkan program TFC (Therapeutic Feeding Center) dan terpantau setiap tahunnya.

\section{METODE PENELITIAN}

Penelitian ini dilaksanakan di Puskesmas Gatak, Puskesmas Weru, dan Puskesmas Sukoharjo terletak diwilayah kerja Dinas Kesehatan Kabupaten Sukoharjo. Dilaksanakan pada bulan September 2016 sampai bulan Februari 2017. Menggunakan desain observasional dengan pendekatan cross sectional. Sampel dipilih dengan menggunakan teknik simple random sampling yang memenuhi kriteria inklusi sebanyak 30 responden. Data pendapatan keluarga, pendidikan ibu, pengetahuan ibu, dan besar keluarga dikumpulkan dengan cara pengisian kuesioner, berat badan balita diukur menggunakan baby scale dan digital scale, nilai $z$-score dihitung menggunakan WHO Anthro. Uji Kolmogrov Smirnov dilakukan untuk mengetahui kenormalan data, data tidak berdistribusi normal maka menggunakan uji Rank Spearman. Bertujuan untuk melihat hubungan antara pendapatan keluarga, pendidikan ibu, pengetahuan ibu, dan besar keluarga dengan perubahan status gizi balita yang mengikuti program TFC.

\section{HASIL PENELITIAN 3.1 Analisis Univariat}

Tabel 1. Distribusi Frekuensi Karakteristik Responden

\begin{tabular}{lcc}
\hline Karakteristik Responden & $\begin{array}{c}\text { Jumlah } \\
(\mathrm{n})\end{array}$ & $\begin{array}{c}\text { Persentase } \\
(\%)\end{array}$ \\
\hline Umur Balita & & \\
12-36 bulan & 24 & 80 \\
37-60 bulan & 6 & 20 \\
\hline Jenis Kelamin Balita & & \\
Laki-laki & 12 & 40 \\
Perempuan & 18 & 60 \\
\hline
\end{tabular}


PROFESI (Profesional Islam) Media Publikasi Penelitian; 2017; Volume 15; No 1.

Website: ejournal.stikespku.ac.id

\begin{tabular}{lcc}
\hline Pendapatan Keluarga & 18 & 60 \\
Kurang & 12 & 40 \\
Cukup & & \\
\hline Besar Keluarga & 24 & 80 \\
Kecil & 6 & 20 \\
Besar & Jumlah & $\begin{array}{c}\text { Persentase } \\
(\%)\end{array}$ \\
\hline Karakteristik Responden & (n) & \\
Pendidikan Ibu & 15 & 50 \\
$<9$ Tahun & 15 & 50 \\
$>9$ Tahun & & \\
\hline Pengetahuan Ibu & 15 & 50 \\
Kurang & 15 & 50 \\
Cukup & & \\
\hline Status Gizi Balita & 18 & 60 \\
Kurang & 12 & 40 \\
Buruk & & \\
\hline
\end{tabular}

Rp 1.000.000,- (pendapatan cukup), dan standar deviasi Rp 224.339,-. Status gizi rata-rata $-2,99$ (status gizi kurang), nilai minimum -4,53 (status gizi buruk), nilai maksimum -2,09 (status gizi kurang), dan standar deviasi 0,72.

Nilai $p$ value dari uji hubungan pendapatan perkapita dengan status gizi balita menggunakan uji Rank Spearman yaitu 0,634 sehingga dapat disimpulkan tidak ada hubungan antara pendapatan perkapita dengan status gizi balita.

\subsubsection{Pendidikan Ibu}

Pengujian hubungan pendidikan ibu dengan status gizi balita dapat dilihat pada Tabel 3 .

Tabel 3. Hubungan Pendidikan Ibu dengan Status Gizi Balita

Berdasarkan Tabel 1. distribusi umur balita tertinggi berusia $12-36$ bulan sebanyak $80 \%$, distribusi jenis kelamin balita tertinggi perempuan sebanyak $60 \%$, distribusi berdasarkan tingkat pendapatan tertinggi pada tingkat pendapatan kurang sebanyak $60 \%$, distribusi berdasarkan besar keluarga tertinggi pada kategori keluarga kecil sebanyak $80 \%$, berdasarkan tingkat pendidikan ibu yaitu pendidikan $>9$ tahun dan $<9$ tahun sebanyak $50 \%$, berdasarkan tingkat pengetahuan ibu pada kategori kurang dan cukup sebanyak 50\%, status gizi balita $60 \%$ berstatus gizi kurang.

\subsection{Analisis Bivariat}

\subsubsection{Pendapatan Keluarga}

Pengujian hubungan pendapatan perkapita dengan status gizi dapat dilihat pada Tabel 2.

Tabel 2. Hubungan Pendapatan Perkapita dengan Status Gizi Balita

\begin{tabular}{ccccccc}
\hline Variabel & N & Mean & $\begin{array}{c}\text { Std. } \\
\text { Deviasi }\end{array}$ & Min & Max & $\begin{array}{c}\boldsymbol{p} \\
\text { value }\end{array}$ \\
\hline $\begin{array}{c}\text { Pend. } \\
\text { Perkapita }\end{array}$ & 30 & 445.976 & 224.339 & 200.000 & 1.000 .000 & \\
Status gizi & 30 & $-2,99$ & 0,72 & $-4,53$ & $-2,09$ & 0,634 \\
\hline
\end{tabular}

Berdasarkan Tabel 2 diketahui bahwa pendapatan perkapita rata-rata $\mathrm{Rp}$ 445.976,(pendapatan cukup), nilai minimum $\mathrm{Rp}$ 200.000,- (pendapatan kurang), nilai maksimum

\begin{tabular}{ccccccc}
\hline Variabel & n & Mean & $\begin{array}{c}\text { Std. } \\
\text { Deviasi }\end{array}$ & Min & Max & $\begin{array}{c}\boldsymbol{p} \\
\text { value }\end{array}$ \\
\hline $\begin{array}{c}\text { Pendidikan } \\
\text { ibu }\end{array}$ & 30 & 10,4 & 1,71 & 6 & 12 & \\
Status gizi & 30 & $-2,99$ & 0,72 & $-4,53$ & $-2,09$ & 0,522 \\
\hline
\end{tabular}

Berdasarkan Tabel 3 Hasil penelitian ini menunjukkan bahwa pendidikan ibu rata-rata 10,4 ( $>9$ tahun), nilai minimum $6(<9$ tahun), nilai maksimum 12 ( $>9$ tahun), dan standar deviasi 1,71. Status gizi rata-rata $-2,99$ (status gizi kurang), nilai minimum $-4,53$ (status gizi buruk), nilai maksimum $-2,09$ (status gizi kurang), dan standar deviasi 0,72 .

Nilai $p$ value dari uji hubungan pendidikan ibu dengan status gizi balita menggunakan uji Rank Spearman yaitu 0,522 sehingga dapat disimpulkan tidak ada hubungan antara pendidikan ibu dengan status gizi balita.

\subsubsection{Pengetahuan Ibu}

Pengujian hubungan pengetahuan ibu dengan status gizi dapat dilihat pada Tabel 4 .

Tabel 4. Hubungan Pengetahuan Ibu dengan Status Gizi Balita

\begin{tabular}{ccccccc}
\hline Variabel & n & Mean & $\begin{array}{c}\text { Std. } \\
\text { Deviasi }\end{array}$ & Min & Max & $\begin{array}{c}\boldsymbol{p} \\
\text { value }\end{array}$ \\
\hline $\begin{array}{c}\text { Pengetahuan } \\
\text { ibu }\end{array}$ & 30 & 57,7 & 10,1 & 33 & 73 & 0,348 \\
Status gizi & 30 & $-2,99$ & 0,72 & $-4,53$ & $-2,09$ & \\
\hline
\end{tabular}


PROFESI (Profesional Islam) Media Publikasi Penelitian; 2017; Volume 15; No 1.

Website: ejournal.stikespku.ac.id

Berdasarkan Tabel 4 diketahui bahwa pengetahuan ibu rata-rata 57,7 (pengetahuan cukup), nilai minimum 33 (pengetahuan kurang), nilai maksimum 73 (pengetahuan cukup), dan standar deviasi 10,1. Status gizi rata-rata $-2,99$ (status gizi kurang), nilai minimum -4,53 (status gizi buruk), nilai maksimum -2,09 (status gizi kurang), dan standar deviasi 0,72 .

Nilai $p$ value dari uji hubungan pendidikan ibu dengan status gizi balita menggunakan uji Rank Spearman yaitu 0,348 sehingga dapat disimpulkan tidak ada hubungan antara pengetahuan ibu dengan status gizi balita.

\subsubsection{Besar Keluarga}

Pengujian hubungan besar keluarga dengan status gizi balita dapat dilihat pada Tabel 5 .

Tabel 5. Hubungan Besar Keluarga dengan Status Gizi Balita

\begin{tabular}{ccccccc}
\hline Variabel & n & Mean & $\begin{array}{c}\text { Std. } \\
\text { Deviasi }\end{array}$ & Min & Max & $\begin{array}{c}\boldsymbol{p} \\
\text { value }\end{array}$ \\
\hline $\begin{array}{c}\text { Besar } \\
\text { Keluarga }\end{array}$ & 30 & 4,23 & 1,3 & 3 & 9 & 0,738 \\
Status gizi & 30 & 30 & $-2,99$ & 0,72 & $-4,53$ & \\
\hline
\end{tabular}

Berdasarkan Tabel 5. diketahui bahwa besar keluarga rata-rata 4,23 (keluarga besar), nilai minimum 3 (keluarga kecil), nilai maksimum 9 (keluarga besar), dan standar deviasi 1,3. Status gizi rata-rata $-2,99$ (status gizi kurang), nilai minimum -4,53 (status gizi buruk), nilai maksimum -2,09 (status gizi kurang), dan standar deviasi 0,72 .

Nilai $p$ value dari uji hubungan besar keluarga dengan status gizi balita menggunakan uji Rank Spearman yaitu 0,738 sehingga dapat disimpulkan tidak ada hubungan antara besar keluarga dengan status gizi balita..

\section{PEMBAHASAN}

\subsection{Pendapatan Keluarga}

Hasil penelitian menunjukkan bahwa distribusi berdasarkan tingkat pendapatan yaitu tertinggi pada tingkat pendapatan kurang sebanyak $60 \%$ dari jumlah sampel. Dengan pekerjaan paling banyak ayah dan ibu adalah sebagai buruh. Tingkat sosial terutama ekonomi mempengaruhi kondisi status gizi balita.
Keluarga dengan status ekonomi menengah kebawah, memungkinkan konsumsi pangan dan gizi terutama pada balita rendah dan hal ini mempengaruhi status gizi pada anak balita (Supariasa, 2012).

Hasil penelitian tidak menunjukkan adanya hubungan antara pendapatan keluarga dengan perubahan status gizi balita. Hal yang menyebabkan tidak adanya hubungan antara pendapatan dengan perubahan status gizi yaitu terkait dengan besar kecilnya pengeluaran keluarga untuk makan, sebab itu pendapatan keluarga secara langsung tidak mempunyai korelasi nyata dengan perubahan status gizi balita pada penelitian ini. Hal ini disebabkan tidak ada kecenderungan bahwa orangtua responden yang mempunyai pendapatan cukup pemenuhan kebutuhan pangannya cukup pula, demikian juga sebaliknya tidak ada kecenderungan bahwa dengan pendapatan yang kurang pemenuhan kebutuhan pangannya juga rendah (Fardhiasih dan Taurina, 2012). Penelitian Amelinda (2016) juga menyebutkan, tidak adanya hubungan status gizi dengan pendapatan karena keluarga dengan pendapatan yang tinggi tidak semua hasil pendapatannya dibelanjakan untuk kebutuhan pangan saja. Sehingga pemenuhan kebutuhan pangan dan gizinya seringkali rendah tetapi kebutuhan yang lain tercukupi.

Berbeda dengan penelitian Vonny dkk (2013), bahwa ada hubungan yang signifikan antara pendapatan keluarga dengan status gizi, dengan pendapatan yang tinggi kebutuhan pangan keluarga pasti tercukupi. Penelitian Eme dkk (2014) juga menyebutkan dengan pendapatan rendah ketahanan pangan keluarga sulit tercapai serta keluarga tersebut cenderung tidak mengakses fasilitas kesehatan modern saat sakit.

\subsection{Pendidikan Ibu}

Kementrian pendidikan membagi pendidikan menjadi 2 kategori yaitu pendidikan $>9$ tahun dan $<9$ tahun. Hasil penelitian menunjukkan tingkat pendidikan ibu $>9$ tahun dan $<9$ tahun sebanyak $50 \%$ dari jumlah sampel. Dengan pendidikan paling banyak yaitu lulusan SMP dan SMA. Tingkat pendidikan dapat mempengaruhi sikap seseorang dalam menyerap informasi serta berperilaku, terutama 
PROFESI (Profesional Islam) Media Publikasi Penelitian; 2017; Volume 15; No 1.

kesehatan terkait gizi dan perilaku hidup sehat (Suhardjo, 2003).

Hasil penelitian tidak menunjukkan adanya hubungan antara pendidikan ibu dengan perubahan status gizi balita. Ibu dengan pendidikan tinggi mempunyai kesempatan bekerja lebih banyak dibanding dengan ibu dengan pendidikan rendah, karena itu ibu dengan pendidikan tinggi cenderung tidak memiliki waktu untuk mengasuh dan memperhatikan kesehatan gizi balitanya. Waktu yang dimiliki oleh ibu digunakan untuk bekerja demi memenuhi kebutuhan rumah tangga. Penelitian Fivi (2006) menyebutkan bahwa ibu yang bekerja diluar rumah cenderung memiliki waktu yang lebih terbatas untuk melaksanakan tugas rumah tangga dibandingkan ibu yang tidak bekerja, oleh karena itu pola pengasuhan anak akan berpengaruh dan pertumbuhan serta perkembangan anak juga akan terganggu.

Penelitian Eme dkk (2014) menyebutkan bahwa terdapat hubungan antara pendidikan dengan status gizi, ibu dengan pendidikan rendah anaknya memiliki resiko tinggi kekurangan gizi dibandingkan dengan ibu dengan pendidikan diatas tingkat menengah. Penelitian Tahereh dkk (2013), menyebutkan ibu dengan pendidikan rendah tidak mengetahui secara baik tentang nilai gizi dalam makanan serta higiene dan sanitasi.

\subsection{Pengetahuan Ibu}

Pengukuran pengetahuan dilakukan dengan menggunakan postest. Menggunakan kuesioner 30 soal benar salah terkait dengan formula WHO, pola asuh, pola pemberian makan, gizi seimbang, penimbangan, garam beryodium, imunisasi, dan PHBS. Hasil penelitian berdasarkan tingkat pengetahuan ibu pada kategori pengetahuan kurang dan cukup sebesar $50 \%$ dari jumlah sampel. Tingkat pengetahuan tentang gizi sangat berpengaruh terhadap perilaku dan sikap dalam memilih makanan untuk anaknya (Maulana, 2012).

Hasil penelitian tidak menunjukkan adanya hubungan antara pengetahuan ibu dengan perubahan status gizi balita. Ibu yang berpengetahuan baik cenderung tidak dapat memenuhi kesehatan gizi anggota keluarga karena tidak didukung dengan kemampuan dalam mengolah serta memanfaatkan bahan pangan dengan baik. Penelitian Murty dkk (2015) menyebutkan bahwa, tidak terdapat hubungan pengetahuan ibu dengan status gizi karena ibu dengan pengetahuan baik belum tentu mempunyai kemampuan dalam mengolah dan memberikan makanan dengan baik dan benar kepada balitanya. Ketersediaan pangan dalam keluarga tidak menjamin kesehatan gizi anggota keluarga jika tidak didukung dengan kemampuan dalam memanfaatkan pangan dengan baik dan benar. Penelitian Fardhiasih dan Taurina (2012) menyebutkan, ibu dengan pengetahuan rendah dengan adanya perkembangan teknologi saat ini dapat dengan mudah mengetahui informasi dari berbagai media, sehingga ibu dapat meningkatkan pengetahuannya.

Berbeda dengan penelitian Oktavianis (2016) menyebutkan bahwa ibu dengan pengetahuan rendah dapat berdampak pada sikap dan perilaku ibu dalam memberikan makanan kepada balita. Studi Christoper dkk (2014), menunjukkan bahwa kurangnya pengetahuan ibu tentang perilaku dan praktik gizi sehat merupakan penyebab utama terjadinya gizi buruk di sebagian besar negara berkembang. Kiranpreet dkk (2015) juga menyebutkan bahwa terdapat pengaruh yang signifikan antara pengetahuan terhadap status gizi anak-anak, meliputi pengetahuan kebersihan dan sanitasi serta praktik pemberian makan.

\subsection{Besar Keluarga}

BKKBN membagi kategori keluarga menjadi dua yaitu keluarga kecil terdiri dari 4 orang dan keluarga besar terdiri dari lebih dari 4 orang. Berdasarkan Tabel 9 menunjukkan bahwa distribusi berdasarkan besar keluarga tertinggi pada kategori keluarga kecil sebanyak $80 \%$ dari jumlah sampel. Keluarga kecil paling banyak terdiri dari 4 orang dengan jumlah anak 2 dan keluarga besar lebih dari 4 orang. Besar keluarga mempengaruhi pengeluaran pangan keluarga, yaitu berdampak pada bertambahnya kebutuhan primer terutama dalam hal makan (Soetjiningsih, 2012). 
PROFESI (Profesional Islam) Media Publikasi Penelitian; 2017; Volume 15; No 1.

Website: ejournal.stikespku.ac.id

Hasil penelitian tidak menunjukkan adanya hubungan antara besar keluarga dengan perubahan status gizi balita. Tuntutan kebutuhan yang semakin bertambah membuat keluarga besar maupun kecil sama-sama harus membagi uang hasil dari bekerja untuk memenuhi kebutuhan hidup. Keluarga kecil dengan perekonomian rendah cenderung tidak dapat memenuhi kebutuhan rumah tangganya. Penelitian Lani dkk (2015), juga menyebutkan bahwa tidak ada hubungan besar keluarga dengan status gizi, keluarga kecil tetapi memiliki ekonomi rendah maka keluarga tersebut tidak dapat memenuhi kebutuhan pangannya. Berbanding terbalik dengan keluarga besar, tetapi keluarga tersebut mampu memunuhi kebutuhannya karena anak yang sudah besar yang dapat membantu ekonomi keluarga sehingga kebutuhan pangan dan gizi dapat tercukupi.

Berbeda dengan penelitian Lisbet dkk (2014), bahwa ada hubungan yang signifikan antara besar keluarga dengan status gizi, semakin besar keluarga semakin sulit untuk memenuhi kebutuhan gizi secara merata. Penelitian Dimpal dkk (2014) menyebutkan bahwa anak yang tinggal dalam keluarga yang besar cenderung mengkonsumsi makanan dengan kualitas yang rendah.

\section{KESIMPULAN}

Kesimpulan dari penelitian ini, tidak ada hubungan antara pendapatan perkapita $(p=0,634)$, pendidikan ibu $(p=0,522)$, pengetahuan ibu $(p=0,348)$, dan besar keluarga $(p=0,738)$ dengan status gizi balita yang mengikuti program TFC (Therapeutic Feeding Center). Keterbatasan penelitian ini adalah dalam program TFC terdapat pemberian edukasi gizi serta pemberian paket modisco, tetapi peserta TFC belum bisa mengaplikasikan edukasi dan saran yang diberikan. Evaluasi modisco melalui angket juga tidak dilakukan sehingga peneliti tidak mengetahui efek pemberian modisco terhadap kenaikan status gizi balita.

\section{REFERENSI}

Amelinda, Calida. 2016. Perbedaan Sosial Ekonomi dan Pengetahuan Gizi Ibu Balita Gizi Kurang dan Gizi Normal. Media Gizi Indonesia. Volume 11, No 1 Hal 55-60.

Atmarita, TS. 2004. Analisis Situasi Gizi dan Kesehatan Masyarakat. Jakarta: Rineka Cipta.

Baiq, S. 2015. Faktor-Faktor Yang Berhubungan Dengan Status gizi Balita 1-5 Tahun di Desa Klepu Kecamatan Pringapus Kabupaten Semarang. Stikes Ngudi Waluyo Ungaran: Semarang.

Bunga CS, Budi S, Nurhandayani U. 2015. Hubungan Lama Perawatan Dengan Status Gizi Setelah Perawatan di Therapeutic feeding center (TFC) Pada Anak Gizi Buruk di Kabupaten Boalemo, Provinsi Gorontalo. Jurnal Ekologi Kesehatan Peneliti Pusat Teknologi Intervensi Kesehatan Masyarakat. Volume 14, No 1 Hal $60-68$.

Christopher Ngwu, Christian Ezeh, Christian Iyiani. 2014. Knowledge of Infant Nutrition among Mothers in Enugu State, South Eastern Nigeria Implications for Social Work Practice. International Journal of Academic Research in Progressive Education and Development. Volume 3, No 1.

Depkes RI. 2003. Indikator Indonesia Sehat 2010 dan Pedoman Penetapan Indikator Provinsi Sehat dan Kabupaten/Kota Sehat. Jakarta.

Dirjen Kesmas RI. CFC Penatalaksanaan Gizi Buruk di Masyarakat. 2011. http://www. gizikia.depkes.go.id/cfc-penatalaksanaangizi-buruk-di-masyarakat/. Diakses tanggal 28 Mei 2016.

Dimpal Arora, Subrata Datta, Soudeep Kr Sau. 2014. An Assessment of Socio-Economic Factors on Nutritional Status in Primary School - A Cross Sectional Study in Purulia 
of West Bengal. International Journal of Occupational Safety and Health. Volume 4 No 2 Page 15 - 18 .

Eme kemenOwoaje, Oluwadolapo Onifade, Adeyimika Desmennu. 2014. Family And Socioeconomic Risk Factors For Undernutrition Among Children Aged 6 To 23 Months In Ibadan Nigeria. The Pan African Medical Journal. 17(161).

Ermaningsih. 2007. Laporan Praktek Lapangan Program Penyuluhan Gizi. Palembang.

Fardhiasih Dwi Astuti, dan Taurina Fitriya Sulistyowati. 2012. Hubungan Tingkat Pendidikan Ibu dan Pendapatan Keluarga Terhadap Status Gizi Anak. Jurnal Kes Mas. Volume 1, No 7.

Fivi, Melva. 2006. Hubungan Pola Asuh dengan Status Gizi Anak Batita di Kecamatan Kuranji Kelurahan Pasar Ambacang Kota Padang Tahun 2004. Jurnal Kesehatan Masyarakat. Volume 1, No 1.

Hickson, M. 2006. Malnutrition and ageing. Nutrition and Dietetic Department, Charing Cross Hospital, Fulham Palace Road, London. Postgrad Med J. No 82 Page 2-8.

Ihsan, M. 2012. Faktor-faktor yang Berhubungan dengan Status Gizi Anak Balita di Desa Teluk Rumbia Kecamatan Singkil Kabupaten Aceh Singkil. Jurnal Gizi Indonesia. 22(3) Hal 44-54.

Ismi, N. 2014. Faktor-Faktor yang Berhubungan dengan Status Gizi Balita Usia 1-5 Tahun di Desa Pekuncen Banyumas. Jurnal Ilmiah Kesehatan. Volume 6, No 1.

Kemenkes RI. 2007. Pedoman Operasional Keluarga Sadar Gizi di Desa Siaga. Jakarta: Direktorat Bina Gizi Masyarakat.

Kemenkes RI. 2011. Kinerja Dua Tahun: Menuju Masyarakat yang Mandiri dan Berkeadilan. Kementerian Kesehatan RI: Jakarta: Dirjen Bina Gizi dan Kesehatan Ibu dan Anak.
PROFESI (Profesional Islam) Media Publikasi Penelitian; 2017; Volume 15; No 1. Website: ejournal.stikespku.ac.id

Kemenkes RI. 2011. Panduan Penyelenggaraan Pemberian Makanan Tambahan Pemulihan Bagi Balita Gizi Kurang. Jakarta: Dirjen Bina Gizi dan Kesehatan Ibu dan Anak.

Kiranpreet Kaur, Kiran Grover, Navjot Kaur. 2015. Assessment of Nutrition Knowledge of Rural Mothers and Its Effectiveness in Improving Nutritional Status of Their Children. Indian Res. J. Ext. Edu. 15 (4) Special Issue.

Lani Karundeng, Amatus Yudi, Rina Kundre. 2015. Hubungan Jarak Kelahiran dan Jumlah Anak Dengan Status Gizi Balita di Puskesmas Kao Kecamatan Kao Kabupaten Halmahera Utara. eJournal Keperawatan (e-Kep). Volume 3 No 1.

Lisbet Rimelfhi, Fadil Oenzil, Asterina. 2014. Hubungan Status Gizi dengan Status Sosial Ekonomi Keluarga Murid Sekolah Dasar di Daerah Pusat dan Pinggiran Kota Padang. Jurnal Kesehatan Andalas. Volume 3 No 2.

Maulana, L. 2012. Gambaran Pengetahuan, Sikap dan Tindakan Terhadap Status Gizi Siswa SD Inpres 2 Pannamu. Makasar: Program Studi Ilmu Gizi Fakultas Keseahtan Masya-rakat Universitas Hasanudin Makassar. Jurnal Kesmas. Volume 2, No 3 Hal 21-24.

Murty Ekawaty M, Shirley E. S. Kawengian, dan Nova H. Kapantow. 2015. Hubungan Antara Pengetahuan Ibu Tentang Gizi dengan Status Gizi Anak Umur 1- 3 Tahun di Desa Mopusi Kecamatan Lolayan Kabupaten Bolaang Mongondow Induk Sulawesi Utara. Jurnal e-Biomedik (eBm). Volume 3, No 2.

Notoatmodjo, S. 2007. Promosi Kesehatan dan Ilmu Perilaku. Jakarta: Rieneka Cipta.

Oktavianis. 2016. Faktor-Faktor Yang Berhubungan Dengan Status Gizi Pada Balita Di Puskesmas Lubuk Kilangan. Jurnal Human Care. Volume 1, No 3. 
PROFESI (Profesional Islam)

Media Publikasi Penelitian; 2017; Volume 15; No 1.

Website: ejournal.stikespku.ac.id

Olaf Müller dan Michael Krawinkel. 2005. Malnutrition and health in developing countries. Department of Tropical Hygiene and Public Health, Ruprecht-KarlsUniversity Heidelberg (Müller), and the Institute of Nutritional Sciences and Depart-ment of Pediatrics, Justus-LiebigUniver-sity Giessen (Krawinkel), Germany. 173 (3).

Panambunan, W dan Sjane, H. 2006. Hubungan Tingkat Pengetahuan Ibu, Status Pekerjaan Ibu dan Pola Makan terhadap Status Gizi Balita di Desa Blimbing Kecamatan Sambirejo Kabupaten Sragen. Jurnal Penelitian Gizi dan Makanan. 48(11) Hal 69-78.

Riskesdas. 2007. Riset Kesehatan Dasar (Riskesdas). Jakarta: Badan Penelitian dan Pengembangan Kesehatan.

Riskesdas. 2010. Riset Kesehatan Dasar (Riskesdas). Jakarta: Badan Penelitian dan Pengembangan Kesehatan.

Riskesdas. 2013. Riset Kesehatan Dasar (Riskesdas). Jakarta: Badan Penelitian dan Pengembangan Kesehatan.

Soetjiningsih. 2012. Tumbuh Kembang Anak. Jakarta: EGC.

Supariasa, I. 2012. Penilain Status Gizi. Jakarta: EGC.

Syafiq. 2007. Anemia dalam Departemen Gizi dan Kesehatan Masyarakat. FKM UI. Eds. Gizi dan Kesehatan Masyarakat. Jakarta: Raja Grafindo Persada.
Tahereh Shafieian, Latiffah A, Mary Huang, Mohsen Mazidi, Majid Ghayo, Golsa Tabatabaei, Gordon Ferns. 2013. Determinants of Nutritional Status in Children Living in Mashhad Iran. International Journal of Pediatrics (Supplement 1). Volume 1 Serial No 2.

Vitolo, M.R. 2008. Some Risk Factors Associated With Overweight,Stunting and Wasting Among Children Under 5 Years Old. Journal de Pediatria. Volume 84, No 3.

Vonny Persulessy, Abidillah Mursyid, Agus Wijanarka. 2013. Tingkat Pendapatan dan Pola Makan Berhubungan Dengan Status Gizi Balita di Daerah Nelayan Distrik Jayapura Utara Kota Jayapura. Jurnal Gizi Dan Dietetik Indonesia. Volume 1, No 3 Hal 143-150.

WHO. 2005. Malnutrition: Quantifying the Health Impact at National and Local Levels. Environmental Burden of Disease Series. No. 12: Geneva.

WHO. 2007. WHO Child Growth Standards 519 Years: New York.

Zulfita. 2013. Faktor-Faktor yang Mempengaruhi Kejadian Gizi Kurang dan Buruk Pada Balita di Wilayah Kerja Puskesmas Air Dingin Kota Padang. 2013. Stikes Mercu Bakti Jaya: Padang 